\section{Trauma Surgery} \& Acute Care Open

\section{Challenges in acute care surgery: penetrating vertebral artery injury in 'extremis' patient}

\author{
Juan Pablo Ramos Perkis (D) ,' Francisco Goyenechea Miralles, ${ }^{2}$ \\ Huascar Rodriguez Galvan, ${ }^{2}$ Julio Benítez Pérez, ${ }^{2}$ Pablo Ottolino ${ }^{1}$
}

'Unidad de Trauma y Urgencias, Complejo Asistencial Doctor Sotero del Rio, Puente Alto, Chile

${ }^{2}$ Cirugía, Complejo Asistencial Doctor Sotero del Rio, Puente Alto, Chile

Correspondence to Dr Juan Pablo Ramos Perkis; jramos.med@gmail.com

\section{CASE SUMMARY}

A young woman was brought to the emergency department after sustaining a gunshot wound to right cervical zone 2. Prehospital personnel describe abundant external bleeding at the accident site. She was admitted to the trauma unit in a 7-minute cardiorespiratory arrest, intubated. A massive transfusion started with 2 units of packed red blood cells and 2 units of fresh frozen plasma through high-flow venous accesses. A hemostatic Foley balloon was inserted through the cervical wound (figure 1A). Her extended focused assessment with sonography in trauma was negative for the abdomen and thorax. After 3 minutes of advanced cardiopulmonary resuscitation, she recovered spontaneous rhythm. During the next few minutes, the patient entered deep shock with blood pressure $70 / 30 \mathrm{~mm} \mathrm{Hg}$, heart rate 110 beats per minute. As she did not achieve hemodynamic improvement despite transfusions, she was transferred to the operating room. An anterior sternocleidomastoid incision was made, maintaining hemostatic control with a Foley balloon. During the cervical surgical exploration, an undamaged common external and internal carotid artery was observed, with bleeding visible behind the neurovascular bundle (figure $1 \mathrm{~B}$ ). Do you suspect a vertebral artery (VA) injury?

\section{WHAT WOULD YOU DO NEXT?}

A. Keep the Foley balloon (damage control) and transfer the patient to a critical unit for resuscitation and subsequent angioembolization.

B. Ligate the VA in zone 1 and use bone wax on the distal end of the lesion (zone 2).

C. Hybrid surgery, proximal and distal end embolization while performing cervicotomy.
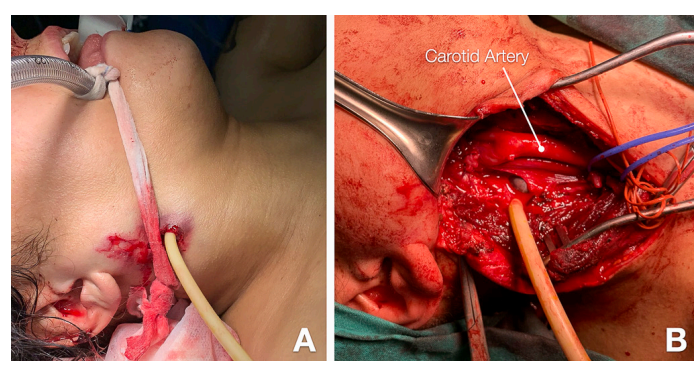

Figure 1 (A) Gunshot wound in cervical zone 2. A Foley balloon is used for hemostatic control. (B) Anterior sternocleidomastoid incision. The carotid vessels are intact, with bleeding from behind the artery.

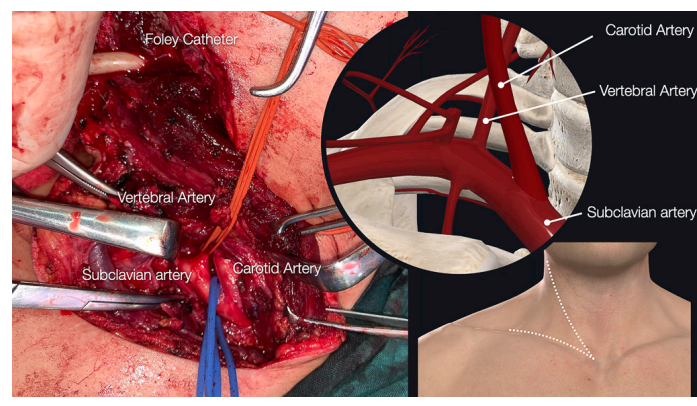

Figure 2 Right supraclavicular extension for proximal control in zone 1 of the vertebral artery.

\section{WHAT WE DID AND WHY}

(B) We ligated the VA in zone 1 and used bone wax on the distal end of the lesion in zone 2.

Our decision was based on the following factors: (1) the patient was in extremis, (2) a hybrid operating room was not available, and (3) the interventional radiologist was not immediately available. An attempt was made to deflate the hemostatic balloon, which caused arterial bleeding from the injured area. The intraoperative point of care showed $\mathrm{pH}$ 7.2 , base excess -10.3 , and hemoglobin 8.2. Given a suspected VA injury in zone 2 in a patient in critical hemodynamic state, and not having immediate angioembolization, we decided to maintain temporary hemostatic control with a Foley balloon and extended the anterior sternocleidomastoid incision to a right supraclavicular approach (figure 2). The VA was identified at its origin from the right subclavian artery (zone 1) and was ligated for proximal control of bleeding (figure 3). The Foley balloon then was removed, resulting in a reduction in bleeding at the surgical site, which originates from the distal portion of the VA in zone 2. To control

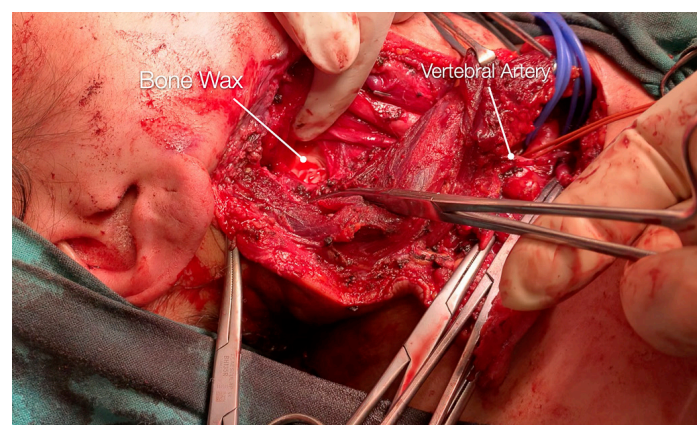

Figure 3 Vertebral artery ligation in zone 1 and tamponade with bone wax in zone 2 . 


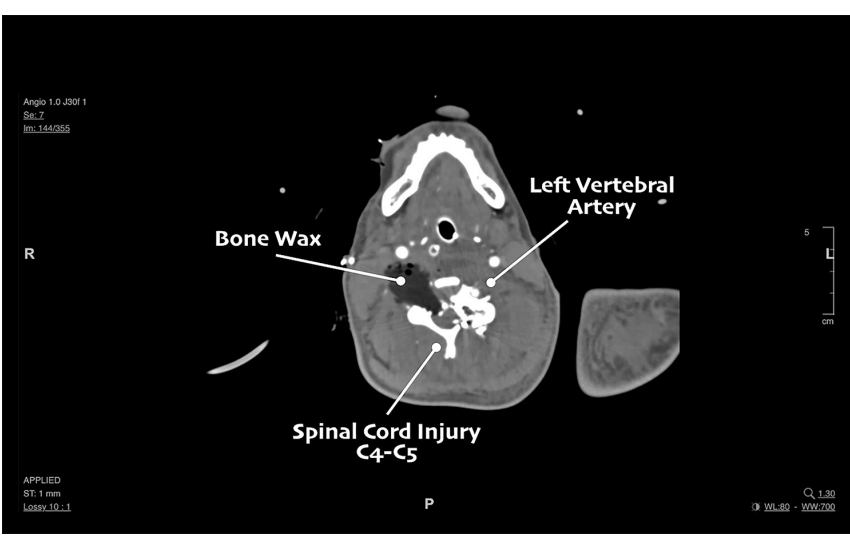

Figure 4 Postoperative tomography showing absence of bleeding from the right vertebral artery and spinal section at the level of C4-C5.

this bleeding, bone wax was applied against the cervical spine, which managed to stop the bleeding (figure 3).

The patient was left in the critical unit to continue resuscitation, achieving hemodynamic stability in the immediate postoperative period. AngioCT was performed, showing the mentioned lesion without active bleeding, but with spinal injury at C4-C5 and cerebellar infarction (figure 4). Unfortunately, due to the severity of her neurological injuries the patient died 4 days after hospitalization.

Due to their low incidence and complex anatomy, VA injuries represent great challenges for the trauma surgeon. This vessel is anatomically divided into three extracranial and four intracranial segments, which makes surgical access difficult. The main mechanism of trauma in the civil environment is by firearm with zone 2 being the most affected. ${ }^{12}$ In patients with hemodynamic stability, CT angiography is the best tool for diagnosis and management decisions. ${ }^{2}$ Endovascular angioembolization is the most frequently used treatment modality with the use of stents as a less common option. ${ }^{23}$ When the patient arrives with hemodynamic instability, as in the case presented, the diagnosis should be intraoperative after the evaluation of other vascular and aerodigestive lesions. ${ }^{1}$ In a damage control context, options such as ligation or packing with gauze are described for a lesion in zone $2 .{ }^{4}$ Control of this lesion is made difficult by its intraosseous route, therefore, use of clips or ligation in the proximal zone (zone 1) and the use of bone wax could be other hemostatic options. In centers that have hybrid operating rooms available, a joint approach can be performed to explore aerodigestive lesions and perform endovascular treatment in anatomic areas that are difficult to access. ${ }^{134}$ Among the complications or sequelae of this injury, we find pseudoaneurysms, arterial-venous fistulas and infarcts in the cerebellar or medullary territory (Wallenberg syndrome), the latter being associated with a high mortality rate. ${ }^{56}$

Twitter Juan Pablo Ramos Perkis @MedJramos Traumasotero, Julio Benítez Pérez @ Juliobeniteze and Pablo Ottolino @ottolinopablo

Contributors All authors contributed equally to this work including writing and critical revisions.

Funding The authors have not declared a specific grant for this research from any funding agency in the public, commercial or not-for-profit sectors.

Competing interests None declared.

Patient consent for publication Not required.

Ethics approval This clinical case has been approved by the Institutional Ethics Committee.

Provenance and peer review Not commissioned; internally peer reviewed.

Open access This is an open access article distributed in accordance with the Creative Commons Attribution Non Commercial (CC BY-NC 4.0) license, which permits others to distribute, remix, adapt, build upon this work non-commercially, and license their derivative works on different terms, provided the original work is properly cited, appropriate credit is given, any changes made indicated, and the use is non-commercial. See: http://creativecommons.org/licenses/by-nc/4.0/.

ORCID iD

Juan Pablo Ramos Perkis http://orcid.org/0000-0001-9698-7572

\section{REFERENCES}

1 Asensio JA, Dabestani PJ, Wenzl FA, Miljkovic SS. Kessler JJ 2nd, Fernandez Ca, Becker T, Cornell D, Siu M, Voigt C, Agrawal DK. A systematic review of penetrating extracranial vertebral artery injuries. J Vasc Surg 2020;71:2161-9.

2 Renfrow JJ, Frenkel MB, Edwards MS, Wilson JA. Evaluation of a traumatic vertebral artery occlusion. World Neurosurg 2017;101:815.e13-815.e17.

3 Leiderman DBD, Zerati AE, Wolosker N, Hoffmann Melo HA, da Silva ES, De Luccia N. Endovascular treatment of penetrating injury to the vertebral artery by a stab wound: case report and literature review. Ann Vasc Surg 2017;45:267.e1-267.e5

4 Gonzales RP. Bleeding from penetrating vertebral artery injury: a difficult injury to control. J Trauma Care 2017;3:1023.

5 Yilmaz MB, Donmez H, Tonge M, Senol S, Tekiner A, Bağlı VA, ve Psödoanevrizma $V A$, ve Literatürün OS, Geçirilmesi G. Vertebrojugular arteriovenous fistula and pseudoaneurysm formation due to penetrating vertebral artery injury: case report and review of the literature. Turk Neurosurg 2015;25:141-5.

6 Uchikawa H, Kai Y, Ohmori Y, Kuratsu J-I. Strategy for endovascular coil embolization of a penetrating vertebral artery injury. Surg Neurol Int 2015;6:117. 